Іван Смірнов,

Національний університет оборони України імені Івана Черняховського, м. Київ

ORCID ID 0000-0002-6844-6290

DOI: $10.33099 / 2617-1775 / 2020-02 / 293-304$

\title{
ШЛЯХИ ПІДВИЩЕННЯ ЕФЕКТИВНОСТІ РЕКЛАМУВАННЯ ВІЙСЬКОВОЇ СЛУЖБИ ДЛЯ ЗАБЕЗПЕЧЕННЯ НАЛЕЖНОГО РІВНЯ КОМПЛЕКТУВАННЯ ВІЙСЬК (СИЛ)
}

У статті проведено аналіз сутності та ролі реклами військової служби у Збройних Силах, чинників, які впливають на організачію і проведення рекламних заходів, визначено шляхи підвищення ефективності рекламування військової служби та забезпечення належного рівня укомплектованості первинних офіцерських посад. Висвітлено переваги та недоліки існуючих засобів реклами, проаналізовано досвід США, Німеччині, Франиії та Україні. Наголошується, щзо кількісний $і$ якісний відбір добровольиів для навчання у вищих військово-навчальних закладах та військових навчальних підрозділах закладів вищої освіти залежить від ефективності рекламної компанії.

Ключові слова: рекламування; навчання; комплектування військ (сил); первинні офімерські посади.

Постановка проблеми. Досвід комплектування Збройних Сил України, насамперед первинних офіцерських посад, офіцерським складом вказує на залежність комплектування від ефективності рекламування військової служби.

У ході попередніх досліджень було виявлено тенденцію до зниження рівня укомплектованості первинних офіцерських посад через неефективність організації і проведення рекламування військової служби у ЗС України, що знижує рівень готовності і здатності військ (сил) до виконання завдань за призначенням.

У Концепції кадрової політики у Збройних Силах України на період до 2020 року [9] зазначено, що заходи із рекламування престижу військової служби у Збройних Силах та їі позитивного сприйняття суспільством є не дуже ефективними.

Вирішення проблеми укомплектованості первинних офіцерських посад 3С України завдяки підвищенню ефективності рекламування військової служби сприятиме підвищенню рівня готовності і здатності військ (сил), а це потребує подальшого дослідження.

Аналіз останніх досліджень і публікацій свідчить, що проблему комплектування військ (сил) особовим складом, у тому числі рекламування військової служби, дослідники розглядали 3 точки зору комплектування 3С України особами рядового, сержантського і старшинського складу.

У статті [8, 103] О. Коваль довів, що організація та проведення рекламних i пропагандистських заходів із молоддю та військовозобов'язаними залишаються актуальними, а також розглянув проблеми формування та функціонування територіальних центрів комплектування та соціальної підтримки (далі - ТЦК та СП) за результатами експерименту. 
Науковець зазначив, що питання пропагування військової служби за контрактом серед осіб офіцерського складу запасу та служби у військовому резерві залишилися поза увагою через відсутність відповідних інструкторів для роботи з населенням.

У статті $[18,25-28]$ В. Хома визначив показники оцінювання ефективності роботи військових комісаріатів із відбору громадян України на військову службу за контрактом на посадах рядового, сержантського та старшинського складу, при цьому показник, який характеризує рівень ефективності проведення рекламної кампанії, не був врахований.

У праці [2, 123] В. Данилов висвітлив сутність і принципи організації рекламних кампаній, спрямованих на створення позитивного образу ЗС України, а також технологій, які вважають проміжною ланкою системи «збройні сили - громадськість». Дослідник визначив вимоги (системність і послідовність у рекламній діяльності та інші) до процесу розроблення, виготовлення та поширення реклами військової служби за контрактом.

Проте у праці [2, 123-128] не розглянуто переваги та недоліки засобів реклами, не визначено конкретні шляхи підвищення ефективності рекламування військової служби для забезпечення належного рівня комплектування Збройних Сил.

У статті $[13,153]$ Г. Радіонов розробив порядок знаходження чинників, що впливають на значення потреб у підготовлених офіцерських кадрах, та методику прогнозування потреб за кожним напрямом підготовки.

За допомогою розробленої методики $[13,157]$ можна виявляти чинники, статистично значущі для кількісного оцінювання очікуваного некомплекту офіцерських кадрів, та добирати відповідну рекурсивну модель. Водночас методика не враховує статистичних чинників ефективності проведення рекламних заходів, які також впливають на кількісне оцінювання очікуваного некомплекту.

У публікаціях [6, 140; 7, 38] також не приділено увагу безпосередньо впливу реклами військової служби на комплектування первинних офіцерських посад, що в сучасних умовах є актуальною науково-прикладною проблемою.

Таким чином, підвищення ефективності рекламування військової служби для забезпечення належного рівня комплектування військ (сил) молодшим офіцерським складом залишається актуальним.

Метою статті $є$ аналіз сутності і ролі реклами військової служби у Збройних Силах, чинників, які впливають на організацію i проведення рекламних заходів, для визначення шляхів підвищення ефективності рекламування військової служби та забезпечення належного рівня укомплектованості первинних офіцерських посад.

Виклад основного матеріалу дослідження. Порядок комплектування ЗС України особовим складом встановлюється Законом України «Про військовий обов'язок і військову службу» [3] та прийнятими відповідно до нього нормативно-правовими актами.

Важливу роль у процесі комплектування ЗС України особовим складом відіграє реклама військової служби, особливо серед молоді, тому що після 
відповідної військової та фахової підготовки у вищих військових навчальних закладах, військових навчальних підрозділах закладів вищої освіти (даліВВНЗ та ВНП ЗВО) молодих офіцерів буде призначено на первинні офіцерські посади.

Реклама військової служби є одним з основних заходів, що забезпечить належний рівень комплектування військ (сил) особовим складом і стане засобом залучення необхідної кількості найбільш освіченої i фізично розвинутої молоді до проходження військової служби у ЗС України, що дасть можливість підтримувати їх бойову готовність на високому рівні та успішно виконувати завдання за призначенням [17].

Реклама військової служби $\epsilon$ складним комплексом заходів, що передбачають серйозну дослідницьку роботу із забезпечення різних категорій населення інформацією про діяльність ЗС України в умовах повсякденної діяльності (мирного часу), в особливий період (під час проведення операції Об'єднаних сил, антитерористичної операції на Сході України) та під час проведення заходів на території України в умовах карантину та поширення COVID-19.

Метою рекламування військової служби $\epsilon$ інформування всіх верств населення про іï перспективи та можливості, створення привабливого іміджу військовослужбовця у цивільного населення, поширення інформації про практичну діяльність ЗС України.

Основними завданнями рекламування військової служби у ЗС України $\epsilon$ доведення до потенційного контингенту населення (передусім молоді) такої інформації:

умов вступу на військову службу (у вищі військові навчальні заклади);

порядку проходження військової служби та її переваг;

пільг для військовослужбовців та членів їхніх сімей;

підвищення престижу військовослужбовців і загалом Збройних Сил у суспільстві;

забезпечення комплектування Збройних Сил якісним, мотивованим, професійним особовим складом (насамперед молодшим офіцерським складом).

Для доведення інформації до споживачів використовують такі основні засоби: зовнішню рекламу, рекламу у пресі, на радіо, телебаченні, кіно- та відеорекламу, а також рекламу в Інтернеті. Переваги та недоліки засобів реклами наведено в таблиці 1. 


\section{Переваги та недоліки засобів реклами}

\begin{tabular}{|c|c|c|}
\hline & & \\
\hline Засоби реклами & Переваги & Недоліки \\
\hline $\begin{array}{c}\text { Зовнішня } \\
\text { реклама }\end{array}$ & $\begin{array}{l}\text { Гнучкість та оперативність; } \\
\text { висока частота повторних } \\
\text { контактів; } \\
\text { слабка конкуренція }\end{array}$ & $\begin{array}{c}\text { Неможливість залучення } \\
\text { вибіркової аудиторії; } \\
\text { обмеженість у у творчих } \\
\text { можливостях впровадження }\end{array}$ \\
\hline Реклама в пресі & $\begin{array}{l}\text { Гнучкість; } \\
\text { широке охоплення; } \\
\text { високий ступінь довіри до } \\
\text { друкованої інформації; } \\
\text { високі вибіркові можливості } \\
\text { спеціалізованих видань; } \\
\text { аудиторія «повторних читачів» }\end{array}$ & $\begin{array}{l}\text { Недостатня оперативність; } \\
\text { короткочасність існування; } \\
\text { висока вартість }\end{array}$ \\
\hline Реклама на радіо & $\begin{array}{l}\text { Масове охоплення; } \\
\text { оперативність надходження в } \\
\text { ефір; } \\
\text { можливість вибору ефективного } \\
\text { часу ефіру та програми; } \\
\text { низька вартість }\end{array}$ & $\begin{array}{l}\text { Відсутність в вибірковості } \\
\text { рекламних повідомлень; } \\
\text { короткочасність рекламної дії }\end{array}$ \\
\hline $\begin{array}{c}\text { Реклама на } \\
\text { телебаченні }\end{array}$ & $\begin{array}{l}\text { Масове охоплення аудиторії; } \\
\text { ефективність дії завдяки } \\
\text { поєднанню зорових, звукових і } \\
\text { рухових ефектів; використання } \\
\text { можливість } \\
\text { виразних електронних спецефектів; } \\
\text { можливість вибору програми та } \\
\text { часу їі виходу в ефір; } \\
\text { оперативність надходження в } \\
\text { ефір }\end{array}$ & $\begin{array}{l}\text { Досить низький вибірковий } \\
\text { соціальний склад аудиторії; } \\
\text { перевантаженість рекламою; } \\
\text { висока вартість; } \\
\text { швидкоплинність рекламної } \\
\text { дії }\end{array}$ \\
\hline $\begin{array}{c}\text { Кіно- та } \\
\text { відеореклама }\end{array}$ & $\begin{array}{l}\text { Ефективність дії на глядача } \\
\text { завдяки поєднанню зорових, } \\
\text { звукових і рухових ефектів; } \\
\text { вибірковість аудиторії } \\
\text { спеціальних програм; } \\
\text { можливість встановлення } \\
\text { моментального ділового контакту }\end{array}$ & $\begin{array}{l}\text { Недостатня } \\
\text { виготовлення; } \\
\text { трудомісткість виробництва; } \\
\text { досить висока вартість; } \\
\text { труднощі в в організації } \\
\text { спеціальних переглядів для } \\
\text { цільових груп населення }\end{array}$ \\
\hline $\begin{array}{l}\text { Реклама в } \\
\text { Інтернеті }\end{array}$ & $\begin{array}{l}\text { Висока оперативність } \\
\text { розміщення; } \\
\text { легка доступність для споживача; } \\
\text { дешевизна порівняно } 3 \text { іншими } \\
\text { традиційними засобами розміщення } \\
\text { реклами; } \\
\text { можливість посилання на } \\
\text { офіційні веб-сайти та додаткову } \\
\text { інформацію }\end{array}$ & 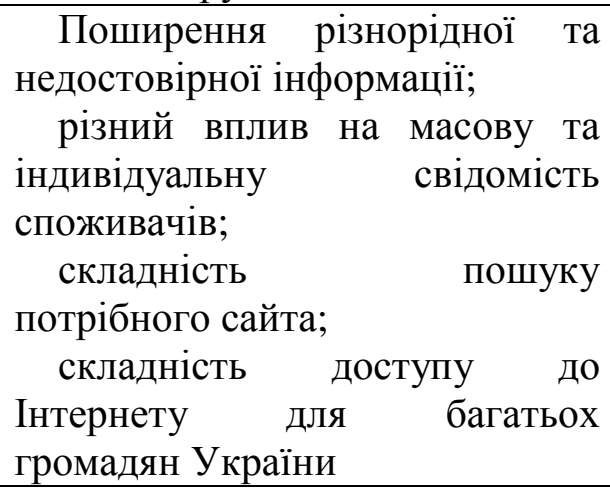 \\
\hline
\end{tabular}

У розвинутих країнах світу рекламу військової служби розглядають як невід'ємну складову забезпечення збройних сил необхідними людськими ресурсами. 
У США спеціальні служби розробляють, виготовляють і поширюють відповідну рекламну продукцію. Крім того, до співпраці долучаються напіввійськові організації: Асоціація Військово-Морської ліги США, Асоціація офіцерів запасу, Асоціація національної гвардії, Національна стрілецька асоціація. Ці організації широко пропагують збройні сили, одночасно виконуючи функції рекламних агентів.

Також у США широко розвинена робота вербувальних пунктів, працівники яких прямо контактують та листуються з юнаками. Вербувальники щорічно охоплюють своїм впливом майже всю молодь країни. Статистика показує: щоб завербувати одного добровольця до збройних сил США, вербувальникам необхідно підтримувати протягом року контакти з 24 кандидатами.

У Німеччині до структури міністерства оборони входить штаб преси та інформації. Армійську службу серед молоді рекламують у військових частинах офіцери відділень по роботі з молоддю.

Крім того, Академія бундесверу у м. Вальдбреле спеціалізується на підготовці фахівців з реклами збройних сил.

У Франції збройні сили рекламують кілька відомств, серед яких основну роль відіграє служба інформації та громадських відносин, підпорядкована міністру оборони.

Отже, аналіз рекламування військової служби у збройних силах інших держав показує значущість реклами для створення ї іміджу та підвищення престижу військової служби, а також важливість роботи з молоддю.

Реклама військової служби у ЗС України покладена на органи військового управління, командувачів, командирів (начальників), штаби, органи моральнопсихологічного забезпечення, територіальні центри комплектування та соціальної підтримки для формування у цивільного населення та військовослужбовців бажання служити у ЗС України та створення привабливого іміджу військової служби. Однак на цей час робота більшості ТЦК та СП з прийняття (призову) найбільш мотивованих громадян України на військову службу є недостатньо ефективною.

Надзвичайно важливим чинником, що сприяє успішному виконанню завдань за призначенням у сучасних збройних конфліктах, під час проведення операції Об'єднаних сил на Сході України та несення бойового чергування $\epsilon$ повнота і якість комплектування органів військового управління, військових частин, підрозділів офіцерським складом, передусім - первинних офіцерських посад молодшими офіцерами.

На організацію і проведення рекламних заходів впливають такі основні чинники:

- наявність дієвих законодавчих та інших нормативно-правових актів стосовно реклами військової служби;

- фінансування рекламної кампанії (ведення фінансово-економічної політики держави стосовно Збройних Сил);

- наявність служб, установ, організацій і підрозділів, які цілеспрямовано рекламують військову службу, відбирають і супроводжують добровольців на 
військову службу чи навчання у вищих військово-навчальних закладах (ВВНЗ) та військових навчальних підрозділах закладів вищої освіти (ВНП ЗВО).

За результатами аналізу законодавчих та інших нормативно-правових актів [3-5; 9; 11; 16-17] з'ясовано, що у них містяться вимоги до необхідності рекламування військової служби у ЗС України.

Найважливішим чинником, від якого залежить ефективність проведення рекламних заходів, є фінансування, однак нині це відбувається за залишковим принципом, хоча рекламні кампанії завжди є фінансово обтяжливими. Так, наприклад, демонстрування однохвилинного рекламного ролика, як показують виборчі перегони до Верховної Ради України у 2019 році, на різних каналах телебачення коштувало від \$ 2,5 до 8 тис.

У США, наприклад, вартість рекламного ролика становить \$ 100 тис., а на комерційному телебаченні деякі рекламні ролики тривалістю 30 с коштують \$ 250 тис. і більше [8]. На рекламу морської піхоти США у 2014 році було витрачено більше $\$ 80$ млн.

Під час рекламування військової служби в різних державах світу використовують такі методи визначення рекламного бюджету: залишкового бюджету; формування бюджету на основі його обсягу за попередній період; встановлення фінансового відсотка до кількості залучених військовослужбовців на військову службу за контрактом; визначення бюджетних цілей та завдань; урахування частки реклами конкурентів; технічного бюджету.

В Україні для рекламування військової служби переважно використовують методи встановлення фінансового відсотка до кількості залучених військовослужбовців на військову службу за контрактом та залишкового бюджету.

Метод встановлення фінансового відсотка до кількості залучених військовослужбовців на військову службу за контрактом полягає у встановленні взаємозв'язку між обсягом рекламних витрат та кількістю військовослужбовців, залучених на військову службу за контрактом: чим більші рекламні витрати на пропаганду військової служби, тим більше бажаючих проходити військову службу.

Метод залишкового бюджету полягає у визначенні короткострокових фінансових можливостей проведення рекламної кампанії після підрахунку всіх інших бюджетних витрат. Цей метод не враховує реальних цілей та завдань рекламування військової служби за контрактом.

Використовуючи традиційні методи визначення рекламного бюджету, командири військових частин, військові комісари ТЦК та СП, органи військового управління визначають обсяг бюджетних витрат для замовлення друкованої рекламної продукції та ефірної реклами на телебаченні і радіо, необхідних для рекламування військової служби.

На організацію і проведення рекламних заходів також впливають спеціальні служби, установи, організації, підрозділи, які цілеспрямовано рекламують військову службу, відбирають і супроводжують добровольців на військову службу. 
Рекламування військової служби та відбір добровольців на військову службу переважно покладено на органи військового управління, обласні та районні ТЦК та СП, військові частини. Наприклад, в обласних ТЦК та СП військову службу рекламує виконує відділ рекрутингу та комплектування, в районних ТЦК та СП- відділення призову. Ці підрозділи закуповують рекламну продукцію та послуги, а також отримують рекламні матеріали від відповідних структурних підрозділів Командування Сухопутних військ ЗС України, розміщують рекламу на білбордах, у громадському транспорті та інших місцях, укладають договори, розробляють і розміщують відео- та аудіоматеріали на місцевому радіо i телебаченні, передовий досвід проходження військової служби висвітлюють у друкованих засобах масової інформації. Періодичність виходу реклами становить: на телебаченні - $1 \ldots 2$ рази на день, на радіо - до 10 разів на день, у друкованих 3MI - 1 раз на тиждень.

Рекламувати проходження військової служби громадянами України та формувати позитивний імідж ЗС України серед населення мають відділи інформаційно-пропагандистського забезпечення управлінь моральнопсихологічного забезпечення Оперативних командувань.

Крім того, вести роз'яснювальну та агітаційну роботу з рекламування військової служби серед населення відповідно до Указу Президента України [17] зобов'язані Головне управління персоналу Генерального штабу ЗС України, Управління преси та інформації МО України, Департамент військової освіти і науки МО України, органи військового управління, ВВНЗ, однак робота службових осіб цих структур [15] на цей час неефективна.

Інші дослідження показують, що соціальні орієнтири та цінності молоді в Україні пов'язані з досягненням матеріального достатку і переважають над усіма іншими життєвими орієнтирами незалежно від категорії опитаних [2; 6-8; $10 ; 13 ; 18]$.

Визначаючи своє ставлення до військової служби, молодь висловлює прагматичні мотиви, тому основну увагу в рекламі доцільно приділити перевагам добровільної військової служби, в ході якої можливе належне матеріальне забезпечення, а в перспективі - отримання житла.

Отже, військова служба має стати бажаною сферою застосування інтелектуальних і фізичних можливостей молоді, наміру випробувати себе, розвинути фізичні якості, що у структурі мотивів посідає друге місце після бажання добре заробляти і випереджає прагнення отримати житло.

Ставлення до військової служби більш яскраво виражено у школярів: їм властиві романтичні настрої щодо ЗС України та військової служби. 3 огляду на це у рекламі, розрахованій на учнів загальноосвітніх навчальних закладів, призовників, важливо наголошувати на можливості здобути у Збройних Силах спеціальність, яка може бути конкурентоздатною у цивільному житті після військової служби, а також спроможність випробувати себе, застосувати інтелектуальні і фізичні можливості.

Важливо в рекламі враховувати і прагнення молоді до незалежності i самостійності, а також допомогти зрозуміти романтику військової служби 
(передусім на офіцерських посадах), благородство і переваги військової професії.

Зрозуміло, що чим більше бажаючих навчатися та менше витрачається коштів на рекламу, тим вища ефективність проведення рекламної кампанії.

Для забезпечення належного рівня комплектування військ (сил) та підвищення ефективності рекламування військової служби Міністерству оборони України, іншим органам військового управління, ТЦК та СП, ВВНЗ та ВНП ЗВО пропонується:

1) рекламування військової служби в ЗС України здійснювати iз використанням усіх засобів реклами;

2) залучати до розроблення та виготовлення рекламної продукції державні та комерційні організації, служби, установи на місцевому та державному рівнях;

3) проводити роз'яснювальну та агітаційну роботу серед молоді через міські ради, обласні й районні державні адміністрації, наприклад, із застосуванням досвіду, висвітленого у [12; 14];

4) рекламування військової служби в 3С України на офіцерських посадах за контрактом серед осіб офіцерського складу запасу та служби у військовому резерві здійснювати щомісячно із нарощуванням зусиль під час рекламної компанї;

5) рекламну компанію проводити під час весіннього та осіннього призову громадян на строкову військову службу;

6) під час рекламної компанії розповсюджувати та розміщувати рекламну продукцію у місцях масового скупчення людей із залученням активістів, а також відбирати та проводити співбесіди із потенційними кандидатами;

7) проводити оцінювання ефективності рекламних кампаній та інші рекламні дослідження для прийняття раціональних рішень.

Висновки. За результатами дослідження визначено, що рекламування військової служби має державну значущість для Міністерства оборони України та Збройних Сил України.

В Україні система рекламування військової служби потребує удосконалення, оскільки актуальною $\epsilon$ тенденція до зниження рівня укомплектованості первинних офіцерських посад, які визначають боєздатність військових частин і підрозділів.

Ефективність рекламних кампаній залежить від фінансування необхідних заходів, наявності спеціальних установ та організацій на державному рівні для виконання завдань рекламування військової служби та підвищення іміджу Збройних Сил, як це зроблено у провідних країнах світу.

Перспективи подальшого дослідження. Надалі планується продовжити дослідження проблем комплектування 3С України офіцерським складом, передусім первинних офіцерських посад.

\section{ЛІТЕРАТУРА}

1. Військова служба за контрактом [Електронний ресурс].- Режим доступу: http://wiki.1551.gov.ua/pages/viewpage.action?pageId=15040951 (дата звернення: 02.10.2020). 
2. Данилов В. Сутність рекламної діяльності Збройних Сил України / В. Данілов // Національна безпека. Політичний менеджмент. 2010 - № 4. - С. 123-128.

3. Закон України “Про військовий обов’язок і військову службу” від 25.03.1992 № 2232XII [Електронний ресурс]. - Режим доступу: http://zakon.rada.gov.ua/laws/show/ 2232-12 (дата звернення: 02.10.2020).

4. Закон України “Про рекламу” від 03.07.1996 № 270/96-ВР [Електронний ресурс]. Режим доступу: http://zakon.rada.gov.ua/laws/show/270/96-\%D0\%B2\%D1\%80/print (дата звернення: 02.10.2020).

5. Закон України "Про соціальний і правовий захист військовослужбовців та членів їх сімей” від 20.12.1991 № 2232-XII [Електронний ресурс]. - Режим доступу: http://zakon.rada.gov.ua/laws/show/2011-12/print (дата звернення: 02.10.2020).

6. Іваницький М. Г. Комплектування Збройних Сил України та інших військових формувань України особовим складом на контрактній основі: досвід, проблеми та перспективи: аналітична доповідь / М. Г. Іваницький, В. Г. Лішавський та ін. - Київ: НАОУ, 2007. - C. 140.

7. Іващенко Г. І. Основні поради щодо рекламування контрактної військової служби в Збройних Силах України [Текст] / Г. І. Іващенко [та ін.]; відп. ред. В. Г. Бережинський; ЦНДІ ЗС України. - Київ, 2003. - 73 с. - Бібліогр.: с. 72.

8. Коваль О. Проблеми формування та функціонування центрів комплектування та соціальної підтримки й шляхи їх вирішення // Ефективність державного управління. - 2017. Вип. 4 (53). Ч. 1. - С. 102-111.

9. Концепція кадрової політики в Збройних Силах України на період до 2020 року: затв. нак. МО України від 26.06.2017 № 342 [Електронний ресурс]. - Режим доступу: http://www.mil.gov.ua/diyalnist/kadrova-politika/konczepcziya-kadrovoi-politiki-v-zbrojnih-silahukraini (дата звернення: 02.10.2020).

10. Методичні рекомендації командирам військових частин та військовим комісарам усіх рівнів Збройних Сил України щодо організації рекламування військової служби за контрактом / В. В. Свтушенко, І. А. Грач, О. В. Панасенко та ін. - Київ: ЦНДІ ЗС України, 2004. - C. 49.

11. Наказ Міністерства оборони України "Про затвердження Змін до Інструкції про організацію виконання Положення про проходження громадянами України військової служби у Збройних Силах України” від 18.06.2019 № 315 [Електронний ресурс]. - Режим доступу: http://search.ligazakon.ua/1_doc2.nsf/link1/RE33709.html.

12. Офіційний інтернет-портал Дніпровської районної в м. Києві Державної адміністрації [Електронний ресурс]. - Режим доступу: http://dnipr.kyivcity.gov.ua/content/ viyskova-sluzhba--za--kontraktom--persp ektyva-zbroynyh-syl.html (дата звернення: 02.10.2020).

13. Радіонов Г. О. Методика прогнозування потреб у підготовлених офіцерських кадрах за напрямками освіти / Г. О. Радіонов // Зб. наук. праць ХУПС. - Харків, 2012. - Вип. 2 (31). - C. 152-157.

14. Свалявський районний військовий комісаріат продовжує набір громадян на військову службу по контракту, всіх бажаючих просимо звертатись до Свалявського РВК [Електронний ресурс]. - Режим доступу: http: //www.svalyava-vlada.gov.ua/filelib/sou/ $260216 \% 20 \% \mathrm{D} 0 \% \mathrm{~A} 0 \% \mathrm{D} 0 \% \mathrm{~B} 5 \% \mathrm{D} 0 \% \mathrm{BA} \% \mathrm{D} 0 \% \mathrm{BB} \% \mathrm{D} 0 \% \mathrm{~B} 0 \% \mathrm{D} 0 \% \quad$ BC $\% \mathrm{D} 0 \% \mathrm{~B} 0 \% 20 \% \mathrm{D} 0 \%$ B2\%D1\%81.pdf (дата звернення: 02.10.2020).

15. Система роботи службових осіб військового управління, військових частин та військових комісаріатів щодо рекламування військової служби за контрактом, служби у військовому резерві та вступу до вищих військових навчальних закладів та військових навчальних підрозділів закладів вищої освіти: затв. Міністром оборони України 16.08.2013.

16. Указ Президента України "Про державну програму розвитку Збройних Сил України на період до 2020 року” від 22.03.2017 № 73/2017 [Електронний ресурс]. - Режим доступу: http://zakon.rada.gov.ua/ laws/show/n0017525-16/print (дата звернення: 02.10.2020). 
17. Указ Президента України "Про Положення про проходження громадянами України військової служби у Збройних Силах України” від 10.12.2008 № 1153/2008 [Електронний pecypc]. - Режим доступу: http://zakon.rada.gov.ua/laws/show/1153/2008/print (дата звернення: 02.10.2020).

18. Хома В. В. Показники оцінювання ефективності роботи військових комісаріатів 3 виявлення (залучення) громадян України на військову службу за контрактом / В. В. Хома // Зб. наук. праць ЦВСД НУОУ імені Івана Черняховського. - Київ, 2013. - № 1 (47). - С. $25-$ 28.

\section{REFERENCES}

1. Military service under contract. Available at: http://wiki.1551.gov.ua/pages/viewpage.action?pageId=15040951.

2. Danilov, V. (2010). The essence of advertising of the Armed Forces of Ukraine. [National Security]. Political management, 4, 123-128.

3. Law of Ukraine «On Military Duty and Military Service» of March 25, 1992 № 2232-XII. Available at: http://zakon.rada.gov.ua/ laws/show/2232-12.

4. Law of Ukraine «On Advertising» of July 3, 1996 № 270/96-VR. Available at: http://zakon.rada.gov.ua/laws/show/270/96-\%D0\%B2\%D1\%80/print.

5. Law of Ukraine «On social and legal protection of servicemen and members of their families» of 20.12.1991 № 2232-XII. Available at: http://zakon.rada.gov.ua/laws/show/2011$12 /$ print.

6. Ivanytsky, M., Lishavsky, V. (2007). Completion of the Armed Forces of Ukraine and other military formations of Ukraine with personnel on a contract basis: experience, problems and prospects: an analytical report. Kyiv: NAOU, 140.

7. Ivashchenko, G. (2003). Basic advice on advertising contract military service in the Armed Forces of Ukraine [Text] G. Ivashchenko [etc.]; resp. ed. V. Berezhinsky [Central Research Institute of the Armed Forces of Ukraine]. Kyiv, 73.

8. Koval, O. (2017). Problems of formation and functioning of staffing and social support centers and ways to solve them. Efficiency of public administration, 4 (53), 102-111.

9. The concept of personnel policy in the Armed Forces of Ukraine for the period up to 2020: approved. nak. Ministry of Defense of Ukraine dated 26.06.2017 № 342. Available at: http://www.mil.gov.ua/ diyalnist/kadrova-politika/konczepcziya-kadrovoi-politiki-v-zbrojnih-silahukraini.

10. Yevtushenko, V., Grach, I., Panasenko, O. (2004). Methodical recommendations to commanders of military units and military commissars of all levels of the Armed Forces of Ukraine regarding the organization of advertising of military service under contract. Kyiv: Central Research Institute of the Armed Forces of Ukraine, 49.

11. Order of the Ministry of Defense of Ukraine «On approval of Amendments to the Instruction on the organization of implementation of the Regulation on military service of citizens of Ukraine in the Armed Forces of Ukraine» of 18.06.2019, № 315. Available at: http://search.ligazakon.ua/1_doc2.nsf/link1/RE33709.html.

12. Official Internet portal of Dniprovska district state administration in Kyiv. Available at: http://dnipr.kyivcity.gov.ua/content/ viyskova-sluzhba-za-kontraktom-perspektyva-zbroynyhsyl.html.

13. Radionov, G. (2012). Methodology for forecasting the needs of trained officers in the areas of education. Coll. Science. against HUPS. Kharkiv, 2 (31), 152-157.

14. Svalyava District Military Commissariat continues to recruit citizens for military service under a contract, all who wish are asked to contact the Svalyava RVC. Available at: http://www.svalyava-vlada.gov.ua/filelib/sou/260216\%20\%D0\%A0\%D0\% $\quad$ B5\%D0\%BA\%D0\% BB $\%$ D0\%B0\%D0\% BC\%D0\%B0\%20\%D0\%B2\%D1\%81.pdf.

15. The system of work of officials of the military administration, military units and military commissariats on advertising military service under contract, service in the military reserve and 
admission to higher military educational institutions and military educational units of higher education institutions: approved. Minister of Defense of Ukraine 16.08.2013.

16. Decree of the President of Ukraine «On the state program of development of the Armed Forces of Ukraine for the period up to 2020» of 22.03.2017, № 73/2017. Available at: http://zakon.rada.gov.ua/laws/ show/n0017525-16/print.

17. Decree of the President of Ukraine «On Regulations on the passage of military service by citizens of Ukraine in the Armed Forces of Ukraine» of 10.12.2008, № 1153/2008. Available at: http://zakon.rada.gov.ua/laws/show/1153/2008/print.

18. Khoma, V. (2013). Indicators of evaluating the effectiveness of military commissariats to identify (involve) citizens of Ukraine in military service under contract. Coll. Science. Proceedings of the Ivan Chernyakhovsky National Center for Social Studies, 1 (47), 25-28.

\section{PЕЗЮME}

Иван Смирнов,

Национальный университет обороны Украины имени Ивана Черняховского

\section{Пути повышения эффективности рекламы военной службы для обеспечения надлежащего уровня комплектования войск (сил)}

В статье проведен анализ сущңности и роли рекламы военной службы в Вооруженных Силах, факторов, влияющих на организацию и проведение рекламных мероприятий, определены пути повышения эффективности рекламы военной службы и обеспечения надлежащего уровня укомплектованности первичных офицерских должностей. Освещены преимущества и недостатки существуюших средств рекламы, проанализирован опыт США, Германии, Франиии и Украины. Отмечается, что количественный и качественный отбор добровольцев для обучения в выстих военно-учебных заведениях и военных учебных подразделениях высших учебных заведений зависит от эффективности рекламной компании.

Ключевые слова: рекламирование; обучение; комплектование войск (сил); первичные офицерские должности.

\section{SUMMARY}

Ivan Smirnov,

National Defence University of Ukraine named after Ivan Cherniakhovskyi

\section{Ways to increase the effectiveness of advertising for military service to ensure the proper level of manning (forces)}

Previous studies have shown a tendency to reduce the level of staffing of primary officer positions due to the inefficiency of organizing and advertising military service in the Armed Forces of Ukraine, which reduces the level of readiness and ability of troops (forces) to perform assigned tasks.

The aim of the article is to analyze the nature and role of military service advertising in the Armed Forces, the factors influencing the organization and conduct of promotional activities, to identify ways to improve the effectiveness of military service advertising and ensure the proper staffing of primary officer positions.

Analysis of research and publications on the topic showed that the problems of manning troops (forces), including advertising the military, were in the field of view of scientists, but attention was paid to the manning of the Armed Forces of Ukraine by privates, sergeants and officers. 
The article identifies the advantages and disadvantages of advertising, the procedure for evaluating the effectiveness of the military service advertising campaign and ways to improve the effectiveness of military service advertising, analyzes the advertising of military service in the United States, Germany, France and Ukraine.

According to the results of the study, the system of advertising military service needs to be improved. The effectiveness of advertising campaigns depends on the funding of necessary measures, the availability of special institutions and organizations at the state level to perform the tasks of advertising military service and enhance the image of the Armed Forces, as is done in leading countries.

The prospect of further research identifies the solution of the problems of staffing the Armed Forces of Ukraine, primarily primary officer positions, officers.

Key words: advertising; teaching; manning of troops (forces); primary officer positions. 